\title{
ABSTRAK \\ PENGARUH KUALITAS PELAYANAN TERHADAP BEHAVIORAL INTENTION (STUDI PADA PELANGGAN PT. POS INDONESIA (PERSERO) CABANG TUAL)
}

\section{Inay Kristina Maranressy, Dosen STIA Darul Racman Tual, Maluku 081233331665, E-mail: maranressykristina@yahoo.co.id}

\begin{abstract}
Variabel bebas yang terdiri dari Tangible (X1), Reliability (X2), Responsiveness (X3), Asurance (X4) dan Empathy (X5) yang berpengaruh signifikan secara simultan terhadap Behavioral Intention (Y). Variabel Tangible (X1), Asurance (X4) dan Empathy (X5) yang berpengaruh signifikan secara partsial terhadap Behavioral Intention (Y), sedangkan Reliability (X2) dan Responsiveness (X3) tidak berpengaruh secara signifikan. Dari kelima variabel bebas yang terdiri dari Tangible (X1), Reliability (X2), Responsiveness (X3), Asurance (X4) dan Empathy (X5), yang paling berpengaruh terhadap Behavioral Intention adalah Empathy
\end{abstract}

kata kunci: kualitas pelayanan, Behavioral intention, pos Indonesia

\section{ABSTRACT \\ THE INFLUENCE OF THE QUALITY OF THE SERVICE FOR BEHAVIORAL INTENTION (A STUDY OF CUSTOMERS PT. POS INDONESIA (PERSERO) THE BRANCH OF TUAL)}

\begin{abstract}
Variable free consisting of tangible (X1), reliability (X2), responsiveness (X3), asurance (X4) and empathy (X5) who is influential significan simultaneously against behavioral intention (Y).Tangible variables (X1), asurance (X4) and empathy (X5) who is influential significan in partsial against behavioral intention (Y), while reliability (X2) and responsiveness (X3) did not influence significantly. Of the variable free consisting of tangible (X1), reliability (X2), responsiveness (X3), asurance (X4) and empathy (X5), has the most influence on behavioral intention is empathy
\end{abstract}

Keywords: quality of service, Behavioral intention, pos indonesia

PT. Pos Indonesia (Persero) memiliki serta aktifitas pengiriman lainnya melintasi sejumlah tugas pokok dan fungsi batas negara dan daerah. Sejak dahulu menjembatani Nusatara melalui kegiatan perusahaan negara ini sangat dinikmati pengiriman surat, warang dan wesel pos, perannya. Pergeseran iklim usaha sebagai 
jawaban atas kebutuhan zaman baru terjadi pada dasawarsa belakangan ini, yang ditandai dengan hadirnya sejumlah perusahaan yang bergerak dalam bidang usaha yang sama. Lembaga keuangan formal maupun informal menjadi pesaing PT. Pos Indonesia dalam hal jasa pengiriman uang, sedangkan pengiriman barang dan surat, PT. Pos berhadapan dengan sejumlah perusahaan penitipan kilat sebagai pesaingnya.

Konteks ini sesungguhnya telah mengisyaratkan bahwa PT. Pos Indonesia sebagai Badan Usaha Milik Negara, telah terlibat dalam situasi persaingan ketat yang tidak dapat terelahkan. Untuk menjamin survivalnya aktivitas lembaga, hendaklah dilakukan serangkaian pelayanan agar organisasi/ lembaga dapat memiliki daya saing yang tinggi. Selain itu, organisasi yang akan survive dalam bisnisnya dituntut juga untuk melakukan pengelolaan usaha secara lebih efisien dan efektif dibandingkan dengan pesaingnya. Tidak ada pilihan selain organisasi dituntut untuk menerapkan serangkaian strategi yang tepat dalam melayani kebutuhan, keinginan, dan harapan dari pelanggannya.

Zeithaml, Berry, dan Parasuraman (1996) menemukan bahwa persepsi tentang
Kualitas Pelayanan memlliki (1) efek positif terhadap loyalitas pelanggan pada perusahaan dan kesediaan untuk membayar dan (2) efek negatif terhadap kecenderungan untuk beralih. Di samping itu, Cronin dan Taylor (1992) serta Anderson dan Sullivan (1993) dalam Zeithaml (2000) menemukan adanya hubungan yang positif antara service quality dengan purchase intentions, serta repurchase intentions berhubungan kuat dengan tingkat kepuasan terhadap suatu produk.

Dalam rangka mengadaptasikan diri dengan realitas pelayanan saat ini, PT. Pos Indonesia berupaya untuk memenuhi kebutuhan dan keinginan pelanggan melalui penyediaan sarana dan prasarana pelayanan yang memadai, staf yang mumpuni dan mekanisme pelayanan yang tidak berbelit. Semua ini diarahkan pada upaya konkrt untuk mempertahanan pelanggan. Realitas berdasarkan pantauan awal menunjukan bahwa budaya pelayanan yang dilakukan masih belum sesuai harapan. Hal ini didasarkan ada sejumlah keluhan pelanggan antara lain: pelanggan/ pensiunan yang menyeluhkan antrian untuk menerima haknya. Lamanya waktu pengiriman surat dan barang dalam lingkungan domestik juga 
menjadi alasan tersendiri dibalik lemahnya pelayanan.

\section{METODE PENELITIAN}

\section{Jenis Penelitian}

Penelitian ini untuk memperoleh gambaran tentang pengaruh variabel Kualitas Pelayanan terhadap Behavioral Intention. Sesuai dengan rumusan masalah dan tujuan penelitian maka penelitian ini menggunakan tipe penelitian descriptive untuk mendapatkan gambaran dari beberapa variabel Kualitas Pelayanan, serta penelitian explanatory yang bermaksud menjelaskan kedudukan variabel-variabel yang diteliti serta hubungan antara satu variabel dengan variabel yang lain (Sugiyono, 2002: 10). Selanjutnya juga bertujuan untuk mengetahui hubungan kausal dan pengaruh antar variabel bebas (X) yaitu Kualitas Pelayanan terhadap variabel terikat (Y) yaitu Behavioral Intention Pelanggan melalui pengujian hipotesis.

\section{Lokasi Penelitian dan Populasi Penelitian}

Populasi adalah jumlah dari keseluruhan obyek (satuan-satuan atau individu-individu) yang karakteristiknya hendak diduga (Djarwanto dan Subagyo, 1994). Atau, Populasi adalah keseluruhan kelompok dari orang-orang, peristiwa, atau barang-barang yang diminatipeneliti untuk diteliti (Malhotra, 1996). Populasi dalam penelitian ini adalah para pelanggan PT. Pos Indonesia (Persero) Cabang Tualyang tidak dapat ditentukan jumlahnya. Sampel ditentukan secara eksidental dengan alasan, pelanggan yang kebetulan dijumpai selama penelitian dan kemudian bersedia menjadi responden yang kemudian dijadikan responden. Jumlah responden mengikuti pendekatan 5 x indikator (Sekaran, 1992), sehingga jumlah sampel terpilih adalah $16 \times 5=80$ orang responden.

\section{Teknik Analisa Data}

Penggunaan teknik analisis ini untuk mengungkap gambaran data lapangan secara deskriptif dengan cara menginterpretasikan hasil pengolahan data nominal yang diperoleh secara empirik. Hasil analisis deskriptif berguna untuk mendukung interpretasi terhadap hasil analisis dengan teknik lainnya. Metode analisis statistik inferensial digunakan untuk menganalisis pengaruh variabel bebas terhadap variabel terikat, baik secara bersama-sama maupun parsial. Alat analisis yang digunakan adalah regresi linier berganda. 


\section{HASIL PENELITIAN}

\section{Hasil Uji Validitas dan Reliabilitas}

Pengujian instrumen penelitian baik dari segi validitasnya maupun reliabilitasnya terhadap 20 responden yang diperoleh dari hasil instrumen penelitian yang dipergunakan adalah valid dimana nilai korelasinya lebih besar dari 0.5 dan koefisien keandalannya (Cronbach Alpha) lebih besar dari 0,6 (Sekaran 2003: 311). Hasil perhitungan validitas dengan menggunakan analisis corelasi bevariat (Pearson), dengan syarat minimal, 3.0, maka data pada tabel 5.1 menunjukkan bahwa keseluruhan item pertanyaan untuk variabel adalah valid dan mempunyai nilai korelasi (r) yang lebih besar dari 0.3 sesuai dengan yang disyaratkan. Dengan demikian berarti bahwa seluruh item dalam instrument penelitian ini dapat dipergunakan dalam analisis selanjutnya.

Kemudian berdasarkan pada hasil uji reliabilitas, maka seluruh variabel dalam instrumen penelitian ini dinyatakan reliabel. Hal ini sesuai dengan kriteria yang telah diajukan, dimana nilai koefesien Cronbach Alpha yang dihasilkan oleh masing-masing variabel lebih besar dari 0,6. Sehingga analisis data dapat dilanjutkan untuk memprediksi hubungan antar variabel sesuai dengan hipotesis yang diajukan.

\section{Hasil Uji Asumsi Klasik}

Pengujian beberapa asumsi perlu dilakukan sebelum dilakukan analisa regresi berganda. Hal ini bertujuan untuk mendapatkan nilai pemeriksa yang tidak bias dan efisien (Best Linear Unbias Estimator/ BLUE) dari satu persamaan regresi berganda dengan metode kuadrat terkecil (Least Squares). Adapun pengujian beberapa asumsi tersebut antara lain sebagai berikut:

\section{Uji Normalitas}

Uji normalitas dimaksudkan untuk menguji apakah data yang digunakan dalam penelitian memiliki distribusi normal. Adapun pengujian normalitas data pada penelitian dilakukan dengan menggunakan pengujian KolmogorovSmirnov Goodness of Fit Test terhadap model yang diuji.

Kolmogorov-Smirnov didapatkan nilai signifikansi residualnya sebesar 1,446 yang berarti lebih besar dari 0,05 ( $\alpha$ $=5 \%$ ), maka dapat disimpulkan bahwa model tersebut normal, sehingga bisa dilakukan regresi dengan Model Linear Berganda untuk memprediksi pengaruh 
variabel Tangibles (X1), Reliability (X2), Responsiveness (X3), Assurance (X4), dan Emphaty (X5) sebagai variable eksplanatory (X) dan Behavioral Intention sebagai variable dependen (Y).

\section{Uji Multikolinieritas}

Multikolinieritas diuji dengan menghitung nilai VIF (Variance Inflating Factor). Bila nilai VIF lebih kecil dari 5 maka tidak terjadi multikolinieritas atau non multikolinieritas. Hasil uji Multikolinieritas bisa dilihat dari hasil perhitungan nilai tolerance yang menunjukkan tidak ada variabel independen yang memiliki nilai tolerance yang kurang dari 0.10 yang berarti tidak ada korelasi antar variabel independen yang nilainya lebih dari 95\%. Hasil perhitungan nilai Variance Inflation Factor (VIF) juga menunjukkan hal yang sama tidak ada variabel independen yang memiliki nilai VIF lebih dari 10. Jadi dapat disimpulkan bahwa tidak ada multikolinieritas antar variabel independen dalam model regresi, sehingga model regresi layak digunakan untuk memprediksi pengaruh variabel $\mathrm{X}$ terhadap variabel Y (Imam Ghozali, 2005).

\section{Uji Heterokedastisitas}

Heteroskedasitas merupakan suatu keadaan dimana gangguan pi (galat dari setiap variabel bebas) semuanya mempunyai varian yang tidak sama. Gejala ini mungkin timbul akibat pengamatan data berupa cross-section. Pada penelitian ini, apabila besamya Z-prediksi terletak antara -3 sampai 3, maka tidak terjadi heteroskedasitas atau melihat gambar standardized scattetplot-nya. Kondisi (asumsi-asumsi) diatas merupakan kondisi ideal, dan apabila terpenuhi maka model regresi yang digunakan telah berlaku secara baik atau memenuhi standar.

\section{Hasil Uji Heterokedastisitas}

Standardized scattet plot berada pada kondisi (asumsi-asumsi) ideal, dan memenuhi model regresi yang digunakan telah berlaku secara balk atau memenuhi standar.

\section{PEMBAHASAN}

\section{Analisis Regresi Linier Berganda}

Dalam pengolahan data dengan menggunakan regresi linear, dilakukan beberapa tahapan untuk mencari hubungan antara variabel independen dan variabel dependen, melalui hubungan variabel Tangibles (X1), Reliability (X2), Responsiveness (X3), Assurance (X4), dan 
Emphaty (X5) terhadap Behavioral

Intention (Y). Tampak pada persamaan hasil uji regresi menunjukkan angka yang signifikan pada Tangibles (X1), Assurance (X4), dan Emphaty (X5). Sedangkan variabel Reliability (X2) dan Responsiveness (X3) tidak signifikan Adapun interpretasi dari persamaan tersebut adalah:

b1 $=0.256$ : Nilai parameter atau koefisien regresi b1 ini menunjukkan bahwa setiap variabel Tangeble (X1) meningkat, maka Behavioral Intention (Y) akan meningkat sebesar 0.256 atau dengan kata lain setiap peningkatan Behavioral Intention (Y) dibutuhkan variabel Tangible (X1) sebesar 0.256, dengan asumsi variabel bebas yang lain tetap atau Cateris Paribus.

b2 = -0,196: Nilai parameter atau koefisien regresi b2 ini menunjukkan bahwa setiap Variabel Reliability (X2) meningkat, maka Behavioral Intention (Y) akan menurun sebesar 0.196 atau dengan kata lain setiap peningkatan Behavioral Intention (Y) dibutuhkan penurunan variabel Reliability (X2) sebesar 0,196 dengan asumsi variabel bebas yang lain tetap atau Cateris Paribus. b3 $=-0.093$ : Nilai parameter atau koefisien regresi b3 ini menunjukkan bahwa setiap variabel Responsiveness (X3) meningkat, maka Behavioral Intention (Y) akan berkurang sebesar 0,093 atau dengan kata lain setiap peningkatan Behavioral Intention (Y) akan mengakibatkan berkurannya Responsiveness (X3) sebesar 0.093, dengan asumsi variabel bebas yang lain tetap atau Cateris Paribus.

b4 $=0.282$ : Nilai parameter atau koefisien regresi b4 ini menunjukkan bahwa setiap variabel Asurance (X4) meningkat, maka Behavioral Intention (Y) akan meningkat sebesar 0.282 atau dengan kata lain setiap peningkatan Behavioral Intention (Y) dibutuhkan variabel Asurance sebesar 0.282, dengan asumsi variabel bebas yang lain tetap atau Cateris Paribus.

b5 $=0.337:$ Nilai parameter atau koefisien regresi b5 ini menunjukkan bahwa setiap variabel Empathy (X5) meningkat, maka Behavioral Intention (Y) akan meningkat sebesar 0.337 atau dengan kata lain setiap peningkatan Behavioral Intention (Y) dibutuhkan variabel Empathy (X5) sebesar 0.337, dengan 
asumsi variabel bebas yang lain tetap atau Cateris Paribus.

Nilai R sebesar 0.542, hal ini menunjukkan bahwa korelasi atau hubungan antara Behavioral Intention (Y) dengan variabel $\mathrm{X} 1, \mathrm{X} 2, \mathrm{X} 3, \mathrm{X} 4$, dan X5 adalah kuat karena mempunyai angka lebih besar dari 0,5. Nilai $\mathrm{R}$ square atau koefisien determinasi sebesar 0,294. Nilai Adjusted R Square yaitu 0,246 (selalu lebih kecil dari $\mathrm{R}$ square). Dengan demikian dapat disimpulkan bahwa variable variabel Tangible (X1), Reliability (X2), Responsiveness (X3), Asurance (X4) dan Empathy (X5) dapat menjelaskan Behavioral Intention (Y) sebesar $24 \%$, sedangkan sisanya (100\% $25 \%=75 \%$ ) dijelaskan oleh variabel lain di luar model dan error.

\section{Hasil Pengujian Hipotesis}

Berdasarkan hasil analisis regresi linier berganda yang telah di kemukakan maka pengujian hipotesis dalam penelitian ini adalah: Untuk menunjukkan variabel Tangible (X1), Reliability (X2), Responsiveness (X3), Asurance (X4) dan Empathy (X5) yang berpengaruh siginifikan terhadap Behavioral Intention (Y) secara simultan. Hasil uji F menunjukan bahwa nilai $F_{\text {hitung lebih besar }}$ dari $\mathrm{F}_{\text {tabel }}(5,993>2,166)$ dengan tingkat signifikan sebesar $0.000<$ dari 0.005 . Hal ini berarti secara simultan variabel ekuitas merek yang terdiri dari Tangible (X1), Reliability (X2), Responsiveness (X3), Asurance (X4) dan Empathy (X5) yang berpengaruh siginifikan dan simultan terhadap Behavioral Intention (Y) Sehingga disimpulkan bahwa hipotesis nol pertama ditolak.

Untuk menunjukkan semua variabel Tangible (X1), Reliability (X2), Responsiveness (X3), Asurance (X4) dan Empathy (X5) yang berpengaruh siginifikan secara partsial terhadap Behavioral Intention (Y) digunakan uji t. Hasil uji Hipotesis kedua menyatakan bahwa Tangible (X1), Reliability (X2), Responsiveness (X3), Asurance (X4) dan Empathy (X5) yang berpengaruh siginifikan secara partsial terhadap Behavioral Intention (Y). Sedangkan Reliability (X2), Responsiveness (X3) tidak berpengaruh secara signifikan terhadap Behavioral Intention. Dengan demikian hipotesis nol kedua diterima.

Variabel yang paling dominan dalam mempengaruhi Behavioral Intention adalah variabel Empathy (X5) yang ditunjukkan dengan nilai Koefisien 
Beta terbesar yaitu sebesar 0,337. Hal ini menunjukkan hipotesis nol ketiga ditolak. Berdasarkan hasil uji statistik maka hipotesis nol pertama ditolak karena variabel bebas yang terdiri dari Tangible (X1), Reliability (X2), Responsiveness (X3), Asurance (X4) dan Empathy (X5) yang berpengaruh siginifikan secara simultan terhadap Behavioral Intention (Y), tetapi hipotesis nol kedua diterima karena hanya variabel Tangible (X1), Asurance (X4) dan Empathy (X5) yang berpengaruh siginifikan secara partsial terhadap Behavioral Intention (Y). hipotesis nol ketiga ditolak karena Empathy (X5) yang berpengaruh lebih dominan terhadap Behavioral Intention.

\section{KESIMPULAN}

1. Variabel bebas yang terdiri dari Tangible (X1), Reliability (X2), Responsiveness (X3), Asurance (X4) dan Empathy (X5) yang berpengaruh siginifikan secara simultan terhadap Behavioral Intention (Y).

2. Variabel Tangible (X1), Asurance (X4) dan Empathy (X5) yang berpengaruh siginifikan secara partsial terhadap Behavioral Intention (Y), sedangkan Reliability (X2) dan
Responsiveness

(X3)

tidak

berpengaruh secara signifikan.

3. Dari kelima variabel bebas yang terdiri dari Tangible (X1), Reliability (X2), Responsiveness (X3), Asurance (X4) dan Empathy (X5), yang paling berpengaruh terhadap Behavioral Intention adalah Empathy.

\section{SARAN}

1. Hasil penelitian memperlihatkan bahwa variabel Empathy adalah variabel yang dominan berpengaruh terhadap kecenderungan pelanggan untuk melanggan lagi produk yang ditawarkan oleh perusahaan. Hal ini menunjukan bahwa sikap responsif dan pelayanan yang handal bukan pilihan yang tepat untuk menjamin kenyamanan pelanggan. Dengan demikian, sikap positif yang menunjukan kepedulian langsung kepada pelanggan menjadi pilihan sikap yang mesti dikembangkan oleh Kantor Pos Indonesia Cabang Tual.

2. Bagi peneliti selanjutnya, diharapkan dapat mengembangkan variabelvariabel penelitian ini dengan menggunakan pendekatan pengukuran Kualitas pelayanan yang lain. 


\section{DAFTAR PUSTAKA}

Brady, Michael K., and J. Joseph Cronin Jr. 2001. Some New Thoughts on Conceptualizing Perceived Service Quality : A Hierarchical Approach. Journal of Marketing. Vol. 65 (July).

Cronin, Josep Jr., M.K. Brady, and G.T. Hull. 1996. Assessing the Effect of Quality, Value, and Customer Satisfaction on Consumer Behavioral Intentions in Service Environments. Journal of Retailing. $76(2)$.

Cronin, Joseph Jr. and A. Taylor. 1992. Marketing Service Quality: A Reexamination and Extention. Journal of Marketing. Vol.56 (July).

Kotler, Philip. 2002. "Manajemen Pemasaran”, Jilid 1, Alih Bahasa, Hendra Teguh, Ronny A. Rusli, dan Benyamin Molan, Prenhallindo, Jakarta.

2002. "Manajemen Pemasaran", Jilid 2, Alih Bahasa, Hendra Teguh, Ronny A. Rusli, dan Benyamin Molan, Prenhallindo, Jakarta.

Loudon, D. L. dan Bitta, A. J. D., (1993).

Consumer behavior, Concepts and Applications. Fouth edition. Singapore: McGraw-Hill

Lupiyoadi, Rambat. 2001. Manajemen Pemasaran Jasa. Edisi Pertama. Salemba Empat. Jakarta.

Malhotra, Naresh K. 1996. Marketing Research an Applied Orientations. Second Edition. Prentice-Hall International Inc, New Jersey.

Parasuraman, A., Leonard L.Berry, and Valarie A. Zeithaml. 1994. Alternative Scales for Measuring Service Quality: A Comparative Assesment Based on Psychometric and Diagnostic Criteria. Journal of Retailing. 70 (3).
Paul Peter J and Jeri C. Olson, 1999. Customer Behavior and Marketing Stategy, McGraw-Hill.

Sekaran, Uma.1992. Research Methods For Business. John Wiley \& Sons ,Inc .A Skill-Building Approach.New York Cichester Brisbane Toronto Singapore. Second Edition.Sugiyono. 1999. Metode Penelitian Bisnis. Alphabeta. Bandung.

Sugiyono. 2002. Metode Penelitian Administrasi, Alfabeta, Bandung

Tjiptono, Fandy. 2000. Perspektif Manajemen dan Manajemen Pemasaran Kontemporer. Edisi Pertama. Penerbit Andi. Yogyakarta.

Zeithaml, Valarie A.. 2000. Service Quality, Profitability, and The Economic Worth of Customers : What We Now and What We Need to Learn. Journal of the Academy of Marketing Science. Vol. 28.

Zeithaml, Valarie A., L. Berry, and A. Parasuraman. $1996 . \quad$ The Behavioral Consequences of Service Quality. Journal of Marketing. 60 (April). 